\title{
Description of Micropygomyia (Sauromyia) vonatzingeni sp. nov. (Diptera, Psychodidae, Phlebotominae) from the states of Pará and Tocantins, Brazil
}

\author{
Eunice A. Bianchi Galati
} Departamento de Epidemiologia, Faculdade de Saúde Pública, Universidade de São Paulo. Av. Dr. Arnaldo 715, 01246-904, São Paulo-SP, Brasil.
egalati@usp.br

\begin{abstract}
Description of Micropygomyia (Sauromyia) vonatzingeni sp. nov. (Diptera, Psychodidae, Phlebotominae) from the states of Pará and Tocantins, Brazil. Both sexes of a new phlebotomine sandfly species Micropygomyia (Sauromyia) vonatzingeni sp. nov. (Diptera, Psychodidae), captured in the Serra das Andorinhas, São Geraldo do Araguaia municipality, Pará state, and Cavalcante municipality, Tocantins state, Brazil, are described and illustrated. This new species belongs to the oswaldoi series and its distinction from the other extant species of the series was made by male and female identification keys. The specific geographical distribution of the oswaldoi series by country and department (or state) is presented.
\end{abstract}

KEYWORDS. Morphology; taxonomy.

RESUMO. Descrição de Micropygomyia (Sauromyia) vonatzingeni sp. nov. (Diptera, Psychodidae, Phlebotominae) dos estados do Pará e Tocantins, Brasil. Ambos os sexos de uma nova espécie de flebotomíneos Micropygomyia (Sauromyia) vonatzingeni sp. nov. (Diptera, Psychodidae) capturada na Serra das Andorinhas, município de São Geraldo do Araguaia, Estado do Pará e no município de Cavalcante, Estado de Tocantins, Brasil são descritos e ilustrados. Esta nova espécie pertence a série oswaldoi e a sua distinção das demais espécies não fósseis da série foi feita por meio de chave de identificação para machos e fêmeas. Apresenta-se a distribuição geográfica das espécies da série oswaldoi, por país e estado (ou departamento).

PALAVRAS-CHAVE. Morfologia; taxonomia.

A male and a female of a new phlebotomine species belonging to the genus Micropygomyia Barretto, 1962, subgenus Sauromyia Artemiev, 1991 were found in 1989 during speleological and archeological studies undertaken in the "Martírios do Araguaia" project, the principal objective of which was to make the Serra das Andorinhas into a state park, under the name of "Parque Estadual Serra dos Martírios/ Andorinhas", which in fact occurred on 07/25/1996.

The specimens were captured in the locality Brejo dos Padres, São Geraldo do Araguaia municipality, in the "Parque Estadual Serra dos Martírios/Andorinhas", state of Pará, Brazil. The vegetation of this locality consists of savannah and gallery forest interspersed among great quartzite rock blocks that form caves and shelters. The altitude is $c a .400 \mathrm{~m}$.

The climate presents two well defined periods: dry (May and June) with a minimum temperature of $16^{\circ} \mathrm{C}$ and wet (November to April) when the maximum temperature reaches $30^{\circ} \mathrm{C}$.

Comparing the female of this new species with two other females captured in February 1985 in Cavalcante municipality, state of Tocantins, which had previously been identified as Mi. oswaldoi by Lustosa E. S. and donated to the entomological collection of the Department of Epidemiology of the Faculdade de Saúde Pública, Universidade de São Paulo, we perceived that we were dealing with specimens of one and the same species.

Micropygomyia, proposed as subgenus of Lutzomyia
França, 1924, was raised by Artemiev (1995) to the genus level of Brumptomyiina. This genus then included the subgenera Micropygomyia, s. str., Sciopemyia Barretto, 1962 and Sauromyia, the latter subgenus being constituted of three species-groups: oswaldoi Barretto, 1962, trinidadensis Artemiev, 1991 and vexator Barretto, 1962.

Galati (1995, 2003a) included Micropygomyia in Sergentomyiina. The subgenus Sauromyia was divided by her into two series: oswaldoi and atroclavata Fairchild, 1955. The species that in the Artemiev's classification belonged to the oswaldoi and trinidadensis groups were included in the oswaldoi series.

The species of the oswaldoi series, as adopted by Galati (1995, 2003a), have been considered by several authors to belong to the genus Lutzomyia, either as constituting the oswaldoi species-group (Theodor 1965; Lewis et al. 1977; Young \& Duncan 1994), or to the oswaldoi or peruensis group/ series, partim, of the subgenus Helcocyrtomyia Barretto, 1962 (Barretto 1962; Martins et al. 1978; Dias et al. 1981) or to the subgenera Lutzomyia, partim, and Trichopygomyia Barretto, 1962, partim (Forattini 1971, 1973).

The oswaldoi series is characterized in both sexes by presenting the palpomere $\mathrm{V}$ longer than the III and the palpomere II shorter than or equal to the IV. Newstead's spines are grouped on the basal part of the palpomere III; antennomere $\mathrm{AV}$ without the papilla; presence of the ventrocervical sensillae, and absence of the setae on the 
anterior margin of the katepisternum. Male: gonostyle with five spines, two being apical; gonocoxite with or without seta tuft in its basal or median area. The females present cibarium with four posterior (horizontal) teeth, the external pair being turned towards the median line or the pharynx; the ascoids' apex reaches the middle or the papilla level of antennomere IV; pharynx with or without spines in its posterior region; spermathecae with or without rings, common sperm duct present.

Sauromyia is constituted of 20 species and is widely distributed in the Americas, from Mexico to Argentina (Martins et al. 1978; Young \& Duncan 1994; Galati 2003a).

The purpose of this paper is to describe and illustrate the new species Micropygomyia (Sauromyia) vonatzingeni, distinguishing it from the other extant species of the oswaldoi series by male and female identification keys, and also to present the distribution of the species by country and state (or department) according to the information available.

\section{MATERIALAND METHODS}

The specimens were clarified in accordance the method described by Forattini (1973) and mounting on microscope slides in NC medium (Cerqueira 1943), the specimens were measured with a Zeiss ${ }^{\circledR}$ eye-piece calibrated according to a standard Zeiss ${ }^{\circledR}$ scale and drawn with an Olympus ${ }^{\circledR}$ clear chamber. All measurements are given in micrometers. The species nomenclature follows Galati $(1995,2003 a)$ and the characters are described in accordance with that same author (2003b). The type-material will be deposited in the entomological collections of the Faculdade de Saúde Pública of the Universidade de São Paulo (FSP/USP). The data base of the Cipa group (1997) was used to determine the geographical distribution, complemented from the relevant literature.

\section{Description of Micropygomyia (Sauromyia) vonatzingeni sp. nov.}

(Figs. 1- 32)

Holotype (male): total body length 2800 .

Head (frontal view) (Fig. 1): coloration brown; length 370; width 300. Eye length 164. Interocular distance 112. Interocular suture separated from antennal suture. Clypeus length 147. Antennomere lengths: AIII 208, AIV 102 (Fig. 3), AV 107 (Fig. 4), AXI 98, AXII 91, AXIII 88, AXIV 65, AXV 45, AXVI 45 (Figs. 5-10). AIII/head length ratio: 0.56:1.0. Antennal formula AIII AX 2, XIX - AXV 1, AXVI 0; ascoids simple and short, their apices on AIV reach only the middle of segment (Fig. 3); papilla absent on AV and AXIII (Fig. 7). Length of the palpomeres: I 40, II 105, III 135, IV 125, V 323. Palpal formula: 1.2.4.3.5. Newstead's spines grouped in the basal third of palpomere III (Fig. 12) and absent on palpomere II (Fig. 11). Labrumepipharynx 175 long. Cibarium (Fig. 16) with sclerotized projection in the centre of the cibarial chamber; membrane covering the cibarial chamber with several sclerotized points; anterior and posterior teeth not observed without 100x

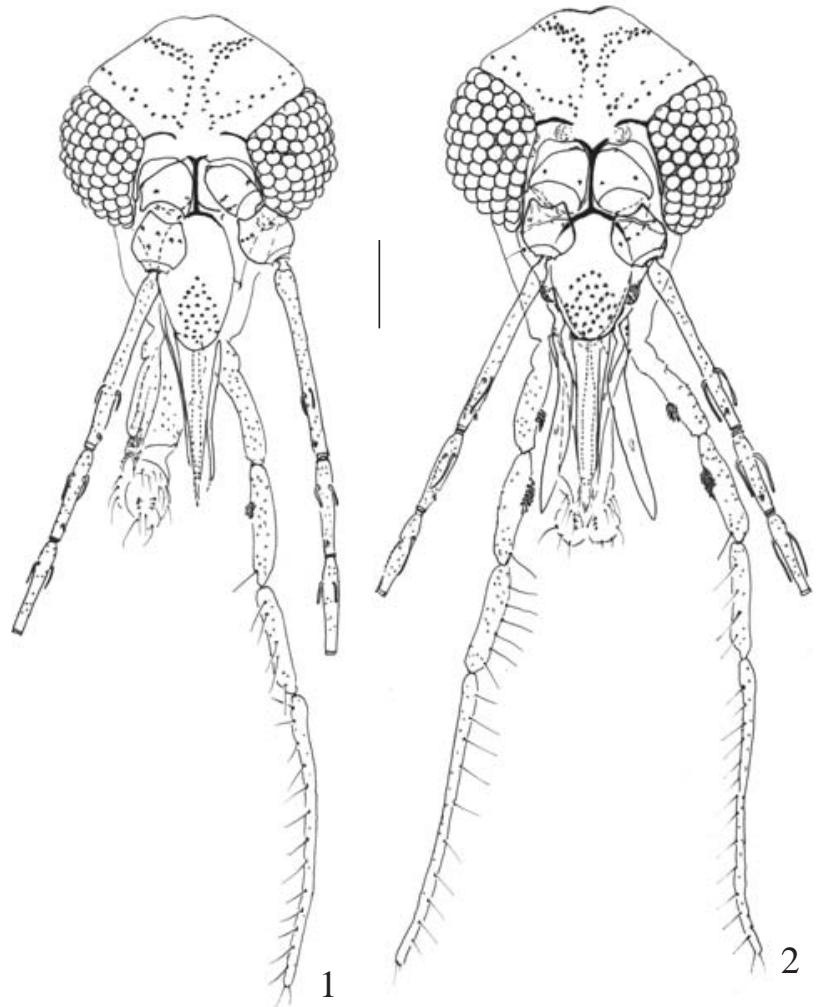

Figs. 1-2. Head, frontal view (holotype $\sigma^{x}$ and allotype + ). Micropygomyia vonatzingeni sp. nov. 1. $0^{x} ; 2$. ․ . Bar $=100 \mu \mathrm{m}$.

objective; sclerotized arch incomplete. Pharynx without conspicuous spines. Labial sutures united. Cervix: ventrocervical sensillae present.

Thorax. Coloration: notum brown, katepisternum, anaepisternum and katepimeron pale brown; paratergite pale. Length 590; mesonotum length 500. Pleurae with 3, 4 proepimeral setae and 8, 10 upper anepisternal setae. Setae absent on the anterior margin of the katepisternum. Suture between katepimeron and metepisternum absent. Wing (Fig. 27): length 1840, width 470; length of vein sections: alpha 470 , beta 368 , gamma 274 , delta 133 , pi $168, \mathrm{R}_{5} 1210$. Length of femora, tibiae, basitarsi and tarsi II+III+IV+V: foreleg 740, 860, 490, 590; midleg 715, 1010, 580, 620; hindleg 740, 1210, 660, 673.

Abdomen 1250 long. Presence of tergal papilla from tergites V to VII. Terminalia (Fig. 30). Gonostyle 133, long, with 5 spines; the spines having the following disposition: two apical, the upper external subapical, the lower external and the internal one implanted in the beginning of the apical third, at the same level. Gonocoxite 235 long x 48 wide, with four thin setae implanted isolated directly in the surface of median region of the gonocoxite. Paramere simple, with the basal half rectangular without setae and the apical, digitiform, covered with thin setae; dorsal margin length 150 . Conical aedeagus; dorsal margin length 98; lateral lobe length 198; width 23. Ejaculatory pump 155 long; piston length 116; pavilion width 30 ; chamber width 20; genital filaments length 348 or 2.9 times the length of genital pump. Tip of genital filaments simple and tapered (Fig. 29). Cercus 155 long. 
Allotype (female): total body length $c a$. 2520. General coloration as that of the male.

Head (Fig. 2) length 370; width 330. Eyes: length 183; width. Interocular suture separated from antennal suture. Interocular distance 120. Clypeus 135 long. Flagellomere lenghts: AIII 205, AIV 95 (Fig. 18) , AV 94 (Fig. 19), AXI 93, AXII 88, AXIII 78, AXIV 65, AXV 48, AXVI 48 (Fig. 20-25). AIII/head length ratio: 0.55. Antennal formula AIII - AXIV 2, AXV 1, XVI 0. Ascoids simple, those on AIV reach the papilla level (Fig. 18). Papilla absent on AV (Fig. 19). Palpomere lengths: I 30, II 95, III 125, IV 125, V 333. Palpal formula: 1.2.(3.4).5. Newstead's spines grouped before the middle of palpomere III (Fig. 14) and on the median third of palpomere II (Fig. 13). Labrum-epipharynx 185 long. Cibarium (Fig. 17): presence of four posterior horizontal teeth turned to the median line with a sclerotized projection between the internal pair; membrane covering the cibarial chamber with several sclerotized points; patch narrow and long; anterior and lateral teeth not observed without 100x objective; posterior bulge evident; arch sclerotized incomplete. Pharynx (Fig. 17) armed with spines in its apical region.

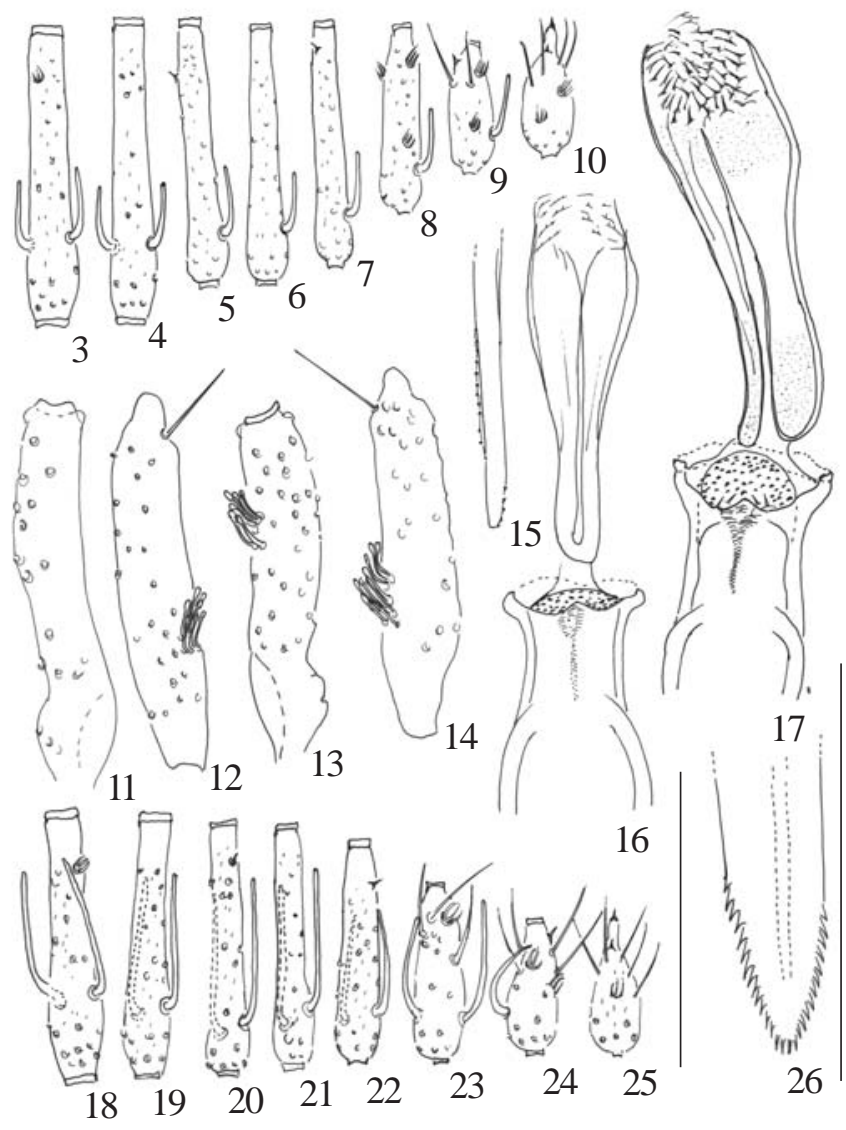

Figs. 3-26. Micropygomyia vonatzingeni sp. nov. (holotype o or allotype + or paratype ㅇ) 3-12 (holotype). 3. A IV; 4. AV; 5. AXI; 6. AXII; 7. AXIII; 8. AXIV; 9. AXV; 10. AXVI; 11 . palpomere II; 12. palpomere III. 13-15 (allotype 우). 13. palpomere II; 14. palpomere III; 15. lacinia of the maxilla; 16 (holotype $\sigma^{7}$ ) cibarium and pharynx. 17-25 (allotype 우); 17. cibarium and pharynx; 18. AIV; 19. AV; 20. AXI; 21. AXII; 22. AXIII; 23. AXIV; 24. AXV; 25. AXVI; 26. hypopharynx (paratype 우). Bar $=100 \mu \mathrm{m}$.
Hypopharynx (Fig. 26) with 13-15 well-delineated apicolateral teeth. Maxilla: lacinia with 5 external teeth disposed in a longitudinal row with about 12 internal teeth (Fig. 15). Labial sutures united.

Cervix: ventrocervical sensillae present.

Thorax length 620; mesonotum 580 long. Pleurae with 4, 5 proepimeral setae, 5, 7 upper anepisternal setae. Setae absent on the anterior katepisternum margin. Suture between katepimeron and metepisternum absent. Wing (Fig. 28): length 1880 and width 540; length of vein sections: alpha 360, beta 300, gamma 300, delta 160, pi 160, R5 1290. Length of femora, tibiae, basitarsi and tarsi II+III+IV+V: foreleg 720; 810; 460; 600; midleg 730; 980, 550, 640; hindleg 800; 1180, 620; 690.

Abdomen length 1530. Tergite VIII with 2, 3 setae on each side. Spermathecae (Fig. 31) 20 long and 13 maximum width; with five rings, the apical as long as the four preceding ones together and twice as wide as the preapical one; individual sperm ducts 120 long $\mathrm{x} 6$ wide at the level of the junction of the spermathecae, where it is more sclerotized; common sperm ducts membranous and smooth, 25 long $\mathrm{x} 8$ wide; terminal knob standing out from the spermatheca. Cercus 143 long.

Type-material. Holotype ơ: BRAZIL, Pará state, São Geraldo do Araguaia municipality, Serra das Andorinhas, Brejo dos Padres (Shannon trap: 18:00 - 20:00 h), collected by von Atzingen N. C. and Silva M. on 15.II.1989. Allotype + idem (human bait) 22.II.1989. Paratypes 2\%: state of Tocantins, Cavalcante municipality, collected by Florencio on 25/27.V.1984 (slide $\mathrm{n}^{\circ}$ 146. 150) - IPTESP) (FSP).

Etymology. The name of this new species Micropygomyia vonatzingeni derives from that of Noé Carlos Barbosa von Atzingen, the president of the Fundação Casa da Cultura de Marabá, state of Pará in recognition of his commitment to the preservation of popular culture and the environment, including his entomological and speleological studies.

Composition and distribution of the oswaldoi series. This series, with the description of this new species, consists of 21 extant and one fossil species, in accordance with Galati (2003a), and others more recently described. These species, with respective synonyms and distribution by country and department (or state), are listed below.

Micropygomyia (Sauromyia) Artemiev, 1991, partim (Artemiev 1991).

Lutzomyia (Helcocyrtomyia) oswaldoi series, partim and series peruensis, partim (Barretto 1962; Martins et al. 1978; Dias et al. 1991).

Lutzomyia, oswaldoi group, partim (Theodor 1965; Lewis et al. 1977; Young \& Duncan 1994).

Lutzomyia (Lutzomyia) França, 1924, partim and Lu. (Trichopygomyia) Barretto, 1962, partim (Forattini 1971, 1973).

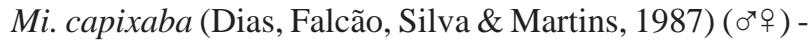
BRAZIL (Bahia, Espírito Santo, Minas Gerais, Pernambuco).

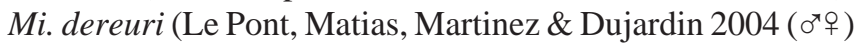
- BOLIVIA (Beni, La Paz). Mi. ferreirana (Barretto, Martins \& 


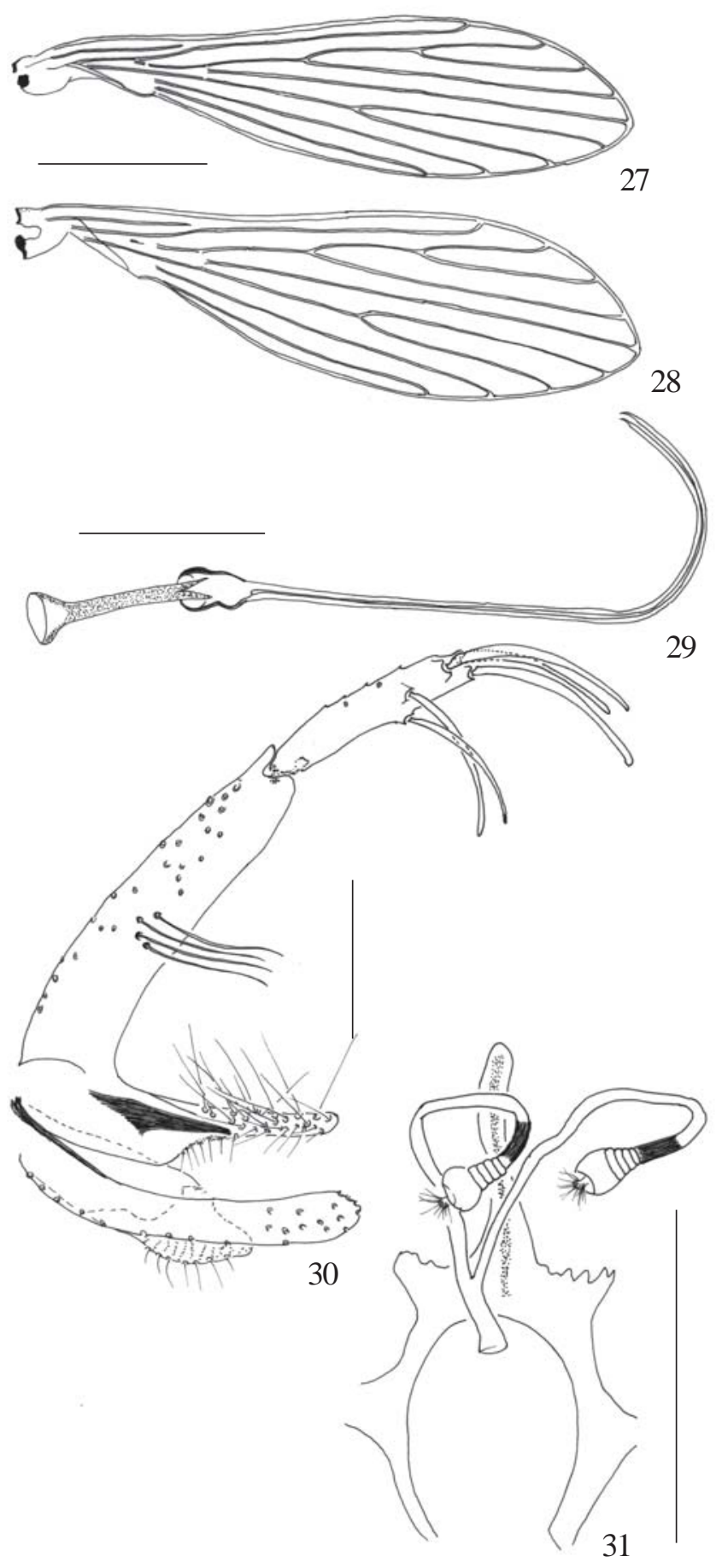

Figs. 27-31. Micropygomyia vonatzingeni sp. nov. (holotype $\sigma^{x}$ or allotype + ). 27. wing ơ; 28. wing + ; 29. ejaculatory pump and ducts $\sigma^{\pi}$; 30. terminalia $\sigma^{x} ; 31$. spermathecae + . Bars: wings $=500 \mu \mathrm{m}$; other figures $=100 \mu \mathrm{m}$.

Pellegrino, 1956) ( ( ${ }^{\top}$ ); Martins, Falcão \& Silva, 1972 (ㅇ) as Lu. borgmeieri Martins et al. 1972- BRAZIL (Espírito Santo, Minas Gerais, Paraná, Rio de Janeiro, Rio Grande do Sul, São Paulo); syn. Lutzomyia borgmeieri Martins, Falcão \& Silva, 1972 (Galati et al. 2002). Mi. fonsecai (Costa Lima, 1932) () - BOLIVIA (Santa Cruz). Mi. longipennis (Barretto, 1946) (ơ); Martins et al. 1962 (甲)- PERU, BRAZIL (Acre, Amapá, Amazonas, Goiás, Maranhão, Mato Grosso, Mato Grosso do Sul, Minas Gerais, Pará, Paraná, Rondônia, São Paulo, Tocantins). Mi. huacalquensis (ơ⿱ ) (Le Pont, Matias, Martinez \& Dujardin 2004 (꾸) - BOLIVIA (Tarija). Mi. machupicchu (Martins, Llanos \& Silva, 1975) ( $\left.\sigma^{\top}\right)$ - PERU (Cusco), BOLIVIA (Beni). Mi. oswaldoi (Mangabeira, 1942) ( $\left.0^{\top}\right)$. Mangabeira, 1942 (ㅇ) BRAZIL (Amapá, Bahia, Ceará, Goiás, Maranhão, Mato Grosso, Mato Grosso do Sul, Minas Gerais, Pará, Pernambuco, Piauí, Rio Grande do Norte, Rondônia, Tocantins). +Mi paterna (Quate, 1963) ( $\left(^{*}\right)$ - MEXICO (Chiapas), Simojovel - Fossil: Oligoceno/Mioceno. Mi. peresi (Mangabeira, 1942) ( $\sigma^{7}$ ); Lucena \& Almeida, 1965 (ㅇ) - FRENCH GUYANA, BRAZIL (Amazonas, Ceará, Goiás, Maranhão, Mato Grosso, Mato Grosso do Sul, Minas Gerais, Pará, Pernambuco, Rio de Janeiro, Rio Grande do Norte, Roraima, Tocantins). Mi. petari Galati, Marassá \& Gonçalves-Andrade, 2003 ( $0^{*}+$ ) - BRAZIL (São Paulo). Mi. pratti (Vargas \& Diaz-Nájera, 1951) (ơ) - MEXICO (Guerrero). Mi. pusilla (Dias, Martins, Falcão \& Silva, 1986) ( $0^{\star}+$ ) - FRENCH GUYANA, BRAZIL (Amapá, Amazonas, Pará, Mato Grosso, Mato Grosso do Sul, Maranhão, Rondônia, Roraima); syn. Phlebotomus sp. de Saul Floch \& Abonnenc, 1944 (Dias et al. 1986). Mi. quechua (Martins, Llanos \& Silva, 1975) (ơ' ) - PERU (Cusco), BOLIVIA (Beni). Mi. quinquefer (Dyar, 1929) (ơ); Lucena \& Almeida, 1965(\%) - BOLIVIA(Santa Cruz), BRAZIL (Bahia, Ceará, Espírito Santo, Goiás, Maranhão, Mato Grosso, Mato Grosso do Sul, Minas Gerais, Paraná, Pernambuco, Rio de Janeiro, Rio Grande do Norte), ARGENTINA (Misiones); syn. Flebotomus rickardi Costa Lima, 1936 (Fairchild \& Hertig 1957). Mi. rorotaensis (Floch \& Abonnenc, 1944) ( $0^{\text {‘ }}+$ ) - PANAMA, TRINIDAD-TOBAGO, COLOMBIA (Antioquia, Choco, Nariño, Valle), VENEZUELA (Amazonas, Yaracuy), SURINAME, FRENCH GUYANA, PERU (Madre de Dios), BRAZIL (Amapá, Amazonas, Pará, Maranhão, Rondônia, Roraima); syn. Phlebotomus sp. de Rorota Floch \& Abonnenc, 1941 (Floch \& Abonnenc 1944). Mi. saccai (Feliciangeli, Ramírez Pérez \& Ramirez, 1989) ( (079) VENEZUELA (Bolivar). Mi. sp. 2 of Araracuara (Morales \& Minter, 1981) $\left(0^{7}\right)$ - COLOMBIA (Caqueta). Mi. trinidadensis (Newstead, 1922) ( (079) - MEXICO (Chiapas, Quintana Roo, Yucatán), BELIZE, GUATEMALA, HONDURAS, NICARAGUA, COSTA RICA, PANAMA, COLOMBIA (Antioquia, Bolívar, Boyacá, Caldas, Cesar, Choco, Cundinamarca, Guajira, Huila, Magdalena, Meta, Nariño, Norte de Santander, Putumayo, Santander, Sucre, Tolima), VENEZUELA (Amazonas, Apure, Aragua, Barinas, Bolivar, Carabobo, Cojedes, Distrito Federal, Falcón, Lara, Mérida, Mirandas. Nueva Esparta, Portuguesa, Sucre, Táchira, Trujillo, Yaracuy, Zulia), TRINIDAD-TOBAGO (Trinidad), SURINAME, FRENCH GUYANA, ECUADOR (Napo, Pichinda), PERU (Cusco, Madre de Dios, Ucayali), BOLIVIA (Beni), BRAZIL (Acre, Amazonas, Amapá, Maranhão, Pará, Rondônia, Roraima, Tocantins); syn. Phlebotomus baduelensis Floch \& Abonnenc, 1942; Phlebotomus yucatanensis Galliard, 1934; P. yucatanensis var. baduelensis Floch \& Abonnenc, 1941 (Fairchild \& Hertig 1948). Mi. villelai (Mangabeira, 1942) (ơ); 



Fig. 32. III and IV tergite $\sigma^{x}$. Left: Micropygomyia vonatzingeni $\mathrm{sp}$. nov. (holotype $\sigma^{\pi}$ ) without tergal papillae; right: Mi. oswaldoi $\sigma^{\star}$, with tergal papillae. Bar $=100 \mu \mathrm{m}$.

Martins et. al. 1962 (ㅇ)as Lutzomyia goiana - BRAZIL (Bahia, Ceará, Goiás, Maranhão, Mato Grosso do Sul, Minas Gerais, Pará, Piauí, Rio Grande do Norte, Rondônia, Sergipe, Tocantins); syn. Lutzomyia goiana Martins, Falcão \& Silva, 1962, (Galati 2003a: 33). Mi. vonatzingeni sp. nov. (ơo ) Galati, 2007. BRAZIL (Pará, Tocantins). Mi. zikani (Barretto, 1950) ( $0^{x}$ + ) - BRAZIL (Espírito Santo, Pará).

\section{TAXONOMIC DISCUSSION}

The morphological characteristics described for $\mathrm{Mi}$. (Sa.) vonatzingeni sp. nov. permit its inclusion in the subgenus Micropygomyia (Sauromyia), series oswaldoi.

The series oswaldoi constitutes a group of insects, the most frequently described and/or drawn characteristics of which (wings, male and female terminalia), are very similar. However, for the males, the combinations of the ratio between the length of the ejaculatory ducts/ejaculatory pump and clypeus/head, setae on the gonocoxite and disposition of the spines on the gonostyle, have permitted the differentiation of the species. Another characteristic that has been useful in the differentiation of the various species, though as yet rarely described, is the presence of papillae on the abdominal tergites - a tendency in the evolutionary process in phlebotomines was to lose the papillae from the basal tergites to the apical ones (Galati 2003b). For the females, beyond the spermathecae, cibarium and pharynx, the external teeth of lacinia of the maxilla have made it possible to distinguish some species from others (Galati 2003b; Dujardin et al. 1999; Le Pont et al. 2004); however, these characteristics have also rarely been presented in the description of the species.
The male of Mi. (Sa.) vonatzingeni sp. nov. is closer to those of Mi. oswaldoi, Mi capixaba and Mi. petari and the female, beyond those of these species, is closer to $\mathrm{Mi}$. ferreirana and Mi.fonsecai. The distinction of the new species from the others of the oswaldoi series may be made by the male and female identification keys presented below.

\section{MALES}

1. Gonostyle with the lower external and inner spines short, their length being slightly longer than the gonostyle's width; gonocoxite with tuft consisting of ca. 20 setae arranged over almost all its surface .Mi. quechua

Gonostyle with the lower external and inner spines' length equivalent to or more than twice the width of the gonostyle; gonocoxite without tuft of setae or, if present, are fewer or in some another arrangement . 2

2(1). Wing narrow, lengths $\mathrm{R} 5 /$ wing width ratio $c a$. 3.6:1.0 .Mi. machupicchu

Wing: lengths R5/wing width ratio $c a$. 3.3:1.0 ... 3

3(2). Wing with delta null Mi. pratti

Wing with clearly positive delta 4

4(3). Gonocoxite with a medium tuft consisting of $c a$. 30 setae Mi. saccai

Gonocoxite without setae or, if present, they number less than 20 5

5(4). Clypeus large, practically as long as the labrumepipharynx and as wide as the eye ...........Mi. peresi

Clypeus shorter than the labrum-epipharynx and narrower than the eye width .................................. 6

6(5). Ejaculatory ducts with tapered, curved apex ........... 7

Ejaculatory ducts with rounded or pointed apex, though not as described above

7(6). Setae of tuft implanted sparsely on the median third of the gonocoxite Mi. longipennis

Setae of the tuft implanted more compactly in the basal third of the gonocoxite Mi. sp. 2 of Araracuara

8(6). Tergal papillae present from tergite III to VII (Fig. 32, on the right) 9

Tergal papillae absent from tergite III (Fig. 32, on the left) 10

9(8). Pharynx with spines in its apical region ...... Mi. petari Pharynx without spines Mi. oswaldoi

10(8). Gonocoxite with semifoliaceous (width ed than that of the ejaculatory duct) setae implanted sparsely or in a compact tuft in its basal or median region 
Gonocoxite without setae in its basal or median region or, if present, they are narrow (width < than that of the ejaculatory duct) .. 14

11(10). Gonocoxite with 5-13 setae in compact tuft. Tergal papillae present only on VI and VII tergite ............12 Gonocoxite with 1-6 setae sparsely implanted. Tergal papillae present at least from V to VII tergite ........13

12(11). Tuft of the gonocoxite with 5-6 setae ....... Mi. dereuri Tuft of the gonocoxite with 8-13 setae ... Mi. quinquefer

13(11). Tergal papillae present on tergite IV. Gonocoxite with 3-6 setae in one line Mi. ferreirana

Tergal papillae absent from tergite IV. Gonocoxite with one seta ..... Mi. huacalquensis

14(10). Gonocoxite with tuft consisting of 12 or more long, thin, curved setae, located between the basal and middle quarters Mi. rorotaensis

Gonocoxite without tuft of setae or, if present, with fewer than 12 and in some other arrangement ...... 15

15(14). Ejaculatory ducts $>3.5$ longer than the ejaculatory pump Ejaculatory ducts $<3.0$ longer than the ejaculatory pump

16(15). Lateral lobe as long as the gonocoxite, clypeus equivalent to $1 / 3$ the head length ..............Mi. zikani

Lateral lobe shorter than the gonocoxite, clypeus longer than $1 / 3$ the head length .. 17

17(16). Terminalia length $c a .370 \mathrm{~mm}$; paramere tapers progressively from the base to the apex .... Mi. villelai Terminalia length ca. $330 \mathrm{~mm}$; paramere tapers abruptly, in such a way that the apical half is digitiform Mi. trinidadensis

18(15). Terminalia $<$ the head length Mi. pusilla Terminalia $>$ the head length 19

19(18). Terminalia clearly longer than the head length ........ Terminalia as long as the head length Mi. capixaba Mi. vonatzingeni $\mathbf{s p . ~ n o v . ~}$

\section{FEMALES}

1. Pharynx with developed teeth . .2

Pharynx with atrophied or absent teeth 8

2(1). Spermathecae smooth, elongated (banana-like) ......... Mi. trinidadensis Spermathecae ringed or with superficial striation ....... 3

3(2). Spermathecae with superficial striation .........Mi. saccai Spermathecae with distinct rings ....
4(3). Spermathecae with 2-3 rings, the apical one tending to spherical shape ........................................................ 5

Spermathecae with $c a$. 10 rings, the apical one clearly elongated Mi. pusilla

5(4). Membrane that covers the cibarial chamber with many sclerotized points ...........Mi. vonatzingeni sp. nov.

Membrane that covers the cibarial chamber without sclerotized points ..6

6(5). Pharynx with the spiny area more highly sclerotized and wider than the anterior one .......... Mi. capixaba

Pharynx with the spiny area without differentiated sclerotization and a little wider than the anterior area

7

7(6). Cibarium with many anterior reduced teeth situated laterally and two considerably more developed ones in the central part; AIII $c a$. $1.5 \mathrm{x}$ the length of the labrum-epipharynx ............................ petari

Cibarium with the anterior vertical teeth not lateral and all the same size; AIII equivalent to the length of the labrum-epipharynx Mi.ferreirana

8(1). Spermathecae smooth, elongated (banana-shaped) ....... Mi. villelai

Spermathecae ringed or elongated with superficial striation .. 9

9(8). Spermathecae elongated with superficial striations, with basal and apical widths practically equal ...Mi. peresi Spermathecae elongated with the apical ring clearly longer and wider than the anterior ones ............. 10

10(9). Spermathecae with 3-6 rings ................... Mi. oswaldoi Spermathecae with more numerous rings 11

11(10). Lacinia of the maxilla with the external teeth in transversal position Mi. longipennis

Lacinia of the maxilla with the external teeth in longitudinal position 12

12(11). Cibarium with the apex of the two pairs of posterior (horizontal) teeth clearly directed towards the central area Mi. quechua

Mi. rorotaensis

Cibarium with the apex of the posterior (horizontal) teeth of the external pair directed towards the pharynx .. 13

13(12). Lacinia of the maxilla with the external teeth disposed in three rows; the most apical being so close to the internal teeth that they seem to constitute four rows Mi. dereuri

Lacinia of the maxilla with the external teeth disposed in two rows; the most apical may seem to form three rows because of the proximity of the internal teeth 14 
14(13). Lacinia of the maxilla with the more external row of external teeth consisting of 11-13 teeth

Mi. huacalquensis

Lacinia of the maxilla with the more external row of external teeth consisting of 6-9 teeth

Mi. quinquefer M. zikani

The females of Mi. pratti and M. machupicchu have not yet been described. The spermathecae of Mi.fonsecai recall those of Mi. ferreirana and Mi. petari. The spermathecae of Mi. sp. 2 of Araracuara recall those of Mi. rorotaensis, Mi. quechua and $M i$ longipennis, though only the internal pair of posterior (horizontal) teeth is directed towards the central area and the external one is turned towards the pharynx. Further, no information is available as regards the external teeth of the lacinia.

\section{REFERENCES}

Artemiev, M. M. 1991. A classification of the subfamily Phlebotominae. Parassitologia 33: 69-77.

Barretto, M. P. 1962. Novos subgêneros de Lutzomyia França, 1924 (Diptera, Psychodidae, subfamília Phlebotominae). Revista do Instituto de Medicina Tropical de São Paulo 4: 91-100.

Cerqueira, N. L. 1943. Novo meio para a montagem de pequenos insetos em lâminas. Memórias do Instituto Oswaldo Cruz 39: 37-41.

Cipa Group. 1997. Computer-aided identification of phlebotomine sandflies of America. Cipa-DB. http://cipa.snv.jussieu.fr (February $5,2007)$

Dias, E. S.; A. V. Martins; A. L. Falcão \& J. E. Silva. 1986. Descrição de uma nova espécie do subgênero Helcocyrtomyia, Lutzomyia pusilla sp. n. (Diptera, Psychodidae, Phlebotominae). Memórias do Instituto Oswaldo Cruz 81: 395-9.

Dias, E. S.; A. L. Falcão; J. E. Silva \& A. V. Martins. 1991. Taxonomic studies of the subgenus Helcocyrtomyia. I. Series oswaldoi (Diptera, Psychodidae, Phlebotominae). Memórias do Instituto Oswaldo Cruz 86: 323-340.

Dujardin, J. P.; F. Le Pont \& E. Martinez. 1999. Quantitative morphological evidence for incipient species within Lutzomyia quinquefer (Diptera: Psychodidae). Memórias do Instituto Oswaldo Cruz 94: 829-836.

Fairchild, G. B. \& M. Hertig. 1948. Notes on the Phlebotomus of Panama (Diptera, Psychodidae). III. P. cruciatus Coq., trinidadensis Newst., and gomezi Nitz. Annals of the Entomological Society of America 41: 247-257.

Fairchild, G. B. \& M. Hertig. 1957. Notes on the Phlebotomus of Panama. XIII. The vexator group, with descriptions of new species from Panama and California. Annals of the Entomological Society of America 50: 325-334.

Floch, H. \& E. Abonnenc. 1944. Phlébotomes de la Guyane française. XI. Sur cinq mâles rencontrés pour la première fois et description de quatre espèces nouvelles. Cayenne, Institut Pasteur de la Guyane et du Territoire de l'Inini, $23 \mathrm{p}$.

Forattini O. P. 1971. Sôbre a classificação da subfamília Phlebotominae nas Américas (Diptera, Psychodidae). Papéis Avulsos de Zoologia 24: $93-111$.

Forattini O. P. 1973. Entomologia Médica. Psychodidae. Phlebotominae. Leishmanioses. Bartonelose, São Paulo, Edgard Blücher/EDUSP, $658 \mathrm{p}$.

Galati, E. A. B. 1995. Phylogenetic systematics of Phlebotominae (Diptera, Psychodidae) with emphasis on American groups. Boletin de la Dirección de Malariología y Saneamiento Ambiental 35: 133-142.

Galati, E. A. B. 2003a. Classificação de Phlebotominae, p. 23-51. In: Rangel, E. F. \& R. Lainson (eds.) Flebotomíneos do Brasil, Rio de Janeiro, Fiocruz, 367 p.

Galati, E. A. B. 2003b. Morfologia, terminologia de adultos e identificação dos táxons da América, p. 53-175. In: Rangel, E. F. \& R. Lainson (eds.) Flebotomíneos do Brasil, Rio de Janeiro, Fiocruz, $367 \mathrm{p}$.

Galati, E. A. B.; J. D. Andrade-Filho \& A. L. Falcão. 2002. Micropygomyia ferreirana (Barretto, Martins \& Pellegrino) as senior synonym of Micropygomyia borgmeieri (Martins, Falcão $\&$ Silva) and denunciation of an error of identification related to this taxon. Entomología y Vectores 9: 156-157.

Le Pont, F.; A. Matias; E. Martinez \& J. P. Dujardin. 2004. Phlébotomes de Bolivie: description de quatre nouvelles espèces de Lutzomyia (Diptera, Psychodidae). Bulletin de la Société Entomologique de France 109: 145-154.

Lewis, D. J.; D. G. Young; G. B. Fairchild \& D. M. Minter. 1977. Proposals for a stable classification of the phlebotomine sandflies (Diptera: Psychodidae). Systematic Entomology 2: 319-32.

Lucena, D. T. \& L. Almeida. 1965. Flebótomos do Nordeste. II. Ocorrência de quatro espécies do subgênero Brumptomyia nessa região. Revista de Malariologia e Doenças Tropicais 17: 257268.

Mangabeira, O. 1942. Contribuição ao estudo dos Flebotomus (Diptera: Psychodidae). Flebotomus oswaldoi Mangabeira, 1942. Memórias do Instituto Oswaldo Cruz 37: 288-294.

Martins, A. V.; A. L. Falcão \& J. E. Silva. 1962. Nota sôbre os flebótomos do Estado de Goiás, com a descrição de duas espécies novas e da fêmea de Lutzomyia longipennis (Barretto, 1946) e a redescrição do macho de L. evandroi (Costa Lima e Antunes, 1936) (Diptera: Psychodidae). Revista Brasileira de Malariologia e Doenças Tropicais 14: 379-399.

Martins, A. V.; A. L. Falcão \& J. E. Silva. 1972. Estudos sobre os flebótomos do Estado de Minas Gerais- IX - Descrição de Lutzomyia borgmeieri sp. n. (Diptera, Psychodidae, Phlebotominae). Studia Entomologia 15: 497-502.

Martins, A. V.; P. Williams \& A. L. Falcão. 1978. American Sand Flies. Rio de Janeiro, Academia Brasileira de Ciências, 195 p.

Theodor, O. 1965. On the classification of the American Phlebotominae. Journal of Medical Entomology 2: 171-197.

Young, D. G. \& M. A. Duncan. 1994. Guide to the identification and geographic distribution of Lutzomyia sand flies in Mexico, the West Indies, Central and South America (Diptera: Psychodidae). Memoirs of the American Entomological Institute 54: 1881 . 